\title{
ARTHROGRYPOSIS MULTIPLEX CONGENITA
}

\author{
D. A. Gibson and N. D. K. Urs, Toronto, Canada
}

One hundred and fourteen patients with arthrogryposis multiplex congenita were treated in the Hospital for Sick Children, Toronto, between 1950 and 1965. This condition has been given many names, but all writers describe a complex of multiple joint contractures and defective muscles, with normal sensation, present at birth. The literature on arthrogryposis and the clinical course of these patients have been reviewed in an attempt to learn more about the condition and its orthopaedic management.

\section{THE CAUSE OF ARTHROGRYPOSIS}

Inheritance seems an unlikely factor because a family history of arthrogryposis is uncommon. Yet Pearson and Fowler (1963) reported two siblings involved, Laitinen and Hirvensalo (1966) a family of four affected siblings, and Lipton and Morgenstern (1955) affected identical twins. Roberts (1929) described an arthrogryposis-like condition in sheep transmitted in an autosomal recessive pattern. Hillman and Johnson (1952) described two pairs of identical twins of which only one in each pair had arthrogryposis, which ruled out a genetic factor in his cases.

Some authors have suggested that mechanical obstruction to intra-uterine foetal movement might produce deformity (Stern 1923, Lewin 1925, Brandt 1947). Increased intra-uterine pressure, hydramnios, oligohydramnios and foetal malposition have been blamed.

Viral infections of the central nervous system have been incriminated (Whittem 1957, Drachman and Banker 1961), but we found only one report of clear-cut chronic inflammatory changes in tissues of the central nervous system, and then only in the meninges overlying the spinal cord in a baby of four and a half months (Price 1933). Toxins have not been identified as the cause of human arthrogryposis, but Whittem (1957) mentioned chronic cyanide intoxication and ergotism in cattle as producing deformities in calves.

Degenerative changes in muscle or anterior horn cells have been held responsible for the deformities. Middleton (1934) interpreted the changes in human and sheep arthrogrypotic muscle as a primary degenerative process in utero analogous to the human dystrophies of later life. Banker, Victor and Adams (1957) also described two patients with primary degeneration of skeletal muscle, and extensive fatty degeneration of affected muscle has been found at necropsy (Howard 1908). Several investigators have found diminution of anterior horn cells, and occasionally disturbed cortical fissuring and enlargement of the cerebral ventricles (Price 1933; Brandt 1947; Fowler 1959; Adams, Denny-Brown and Pearson 1962). Ek (1958) described organic cerebral lesions in four of his eight cases.

Aplasia of muscle rather than degeneration has been postulated (Sheldon 1932, Hillman and Johnson 1952). Embryonic arrest of muscle development, with failure of limb rotation (Badgley 1943) and amyoplasia secondary to failure of the central nervous system to develop have been suggested (Gilmour 1946, Brandt 1947).

Banker et al. (1957) defined two major forms of arthrogryposis, myopathic and neuropathic, depending on the site of the primary lesion, but sorting patients into one or other of these groups on the basis of clinical findings is often difficult. Regardless of the primary site of the lesion, joint contractures or failure of proper joint development can follow any condition, paralytic or obstructive, that prevents the joints from moving during foetal life (Drachman and Coulombre 1962). 
We believe that arthrogryposis is due to a failure of normal development. It is not necessary to ascribe all the different patterns of deformity to a single cause. The condition includes a variety of disease entities.

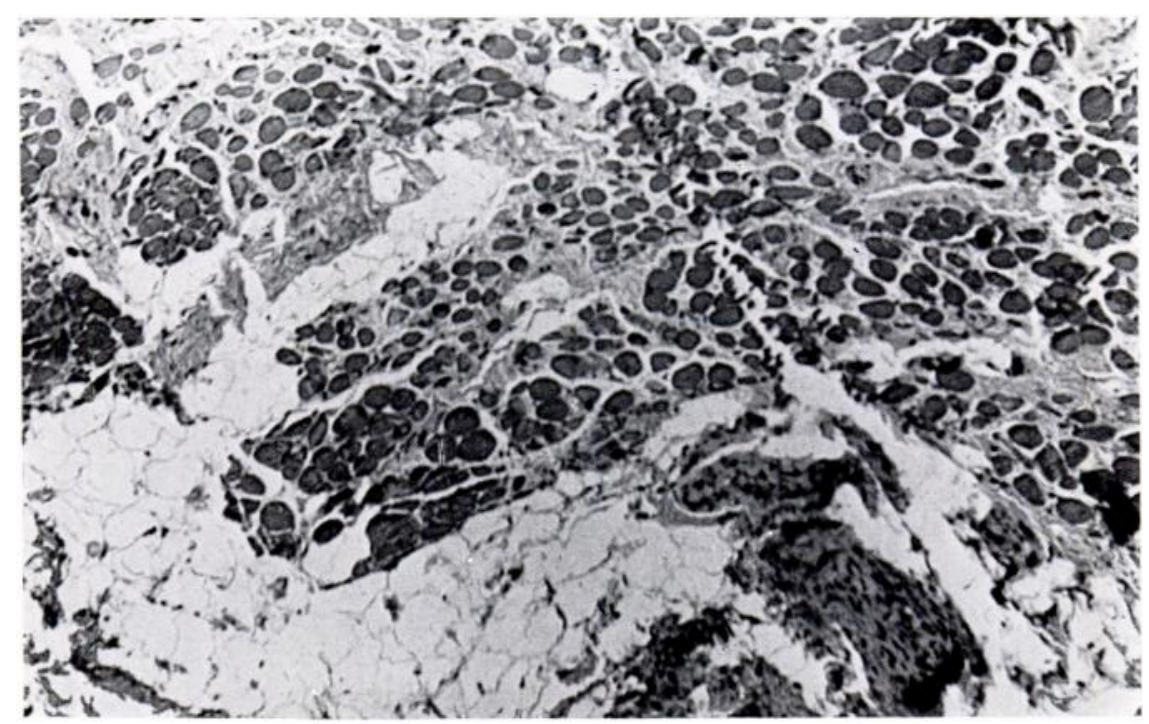

FIG. 1

Arthrogrypotic muscle, low power. Note the variation in fibre size and the increase in fibrous and fatty tissue.

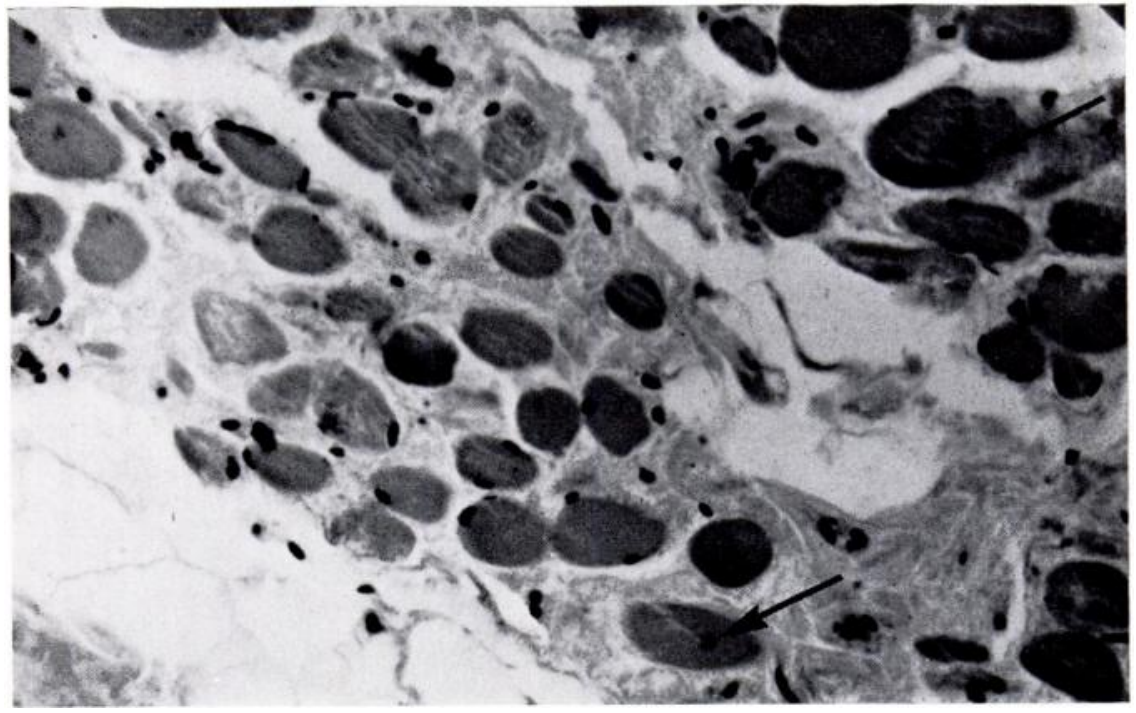

FIG. 2

Arthrogrypotic muscle, high power. Marked variation in fibre size and increased fibrous and fatty tissue are seen, with occasional displacement of the nucleus towards the centre of the fibre (arrows).

\section{TISSUE CHANGES IN ARTHROGRYPOSIS}

The skin of children with arthrogryposis is thin and smooth. The underlying muscle is pale and thin and often replaced by fat or fibrous tissue. The capsules and ligaments of the joints are thickened and the articular surfaces abnormally shaped. Narrowing of the spinal 
TABLE I

Analysis of Patients Treated for Arthrogryposis at Hospital for Sick CHILdRen 1950-65

\begin{tabular}{|c|c|c|c|c|}
\hline Total number of patients & . & . & . & 114 \\
\hline Deaths & . & . & . & 15 \\
\hline $\begin{array}{r}\text { Re-examined: boys } \\
\text { girls }\end{array}$ & $\begin{array}{l}43 \\
39\end{array}$ & . & . & 82 \\
\hline $\begin{array}{l}\text { untraced } \\
\text { too distant }\end{array}$ & $\begin{array}{r}12 \\
5\end{array}$ & . & . & 17 \\
\hline
\end{tabular}

TABLE II

Family History of Anomalies in Eighty-two Patients

\begin{tabular}{|c|c|c|}
\hline Anomaly & $\begin{array}{l}\text { Parents and } \\
\text { sibling }\end{array}$ & $\begin{array}{l}\text { Other } \\
\text { relatives }\end{array}$ \\
\hline Club foot & 5 & 2 \\
\hline Metatarsus varus. & 2 & - \\
\hline Dislocated hip & 2 & - \\
\hline Leg length discrepancy . & 1 & - \\
\hline Flexion contracture at any joint & 1 & - \\
\hline
\end{tabular}

TABLE III

Obstetrical History (Eighty-two Patients)

\begin{tabular}{|c|c|c|}
\hline & & $\begin{array}{l}\text { Number of } \\
\text { cases }\end{array}$ \\
\hline \multicolumn{3}{|c|}{ Complications of pregnancy } \\
\hline \multirow{2}{*}{\multicolumn{2}{|c|}{$\begin{array}{l}\text { Virus infection in first trimester } \\
\text { Trauma in first trimester }\end{array}$}} & 2 \\
\hline & & 2 \\
\hline Drugs in first trimester & . & 1 \\
\hline \multicolumn{2}{|l|}{ Diabetes . . . } & 1 \\
\hline \multicolumn{2}{|l|}{ Bleeding in third trimester. } & 1 \\
\hline \multicolumn{3}{|l|}{ Foetal activity } \\
\hline Normal & . & 50 \\
\hline Diminished & . & 28 \\
\hline Excessive. & . & 4 \\
\hline \multicolumn{3}{|l|}{ Labour } \\
\hline Normal . . & . & 61 \\
\hline Difficult prolonged & . & 15 \\
\hline Caesarean section & . & 6 \\
\hline \multicolumn{3}{|l|}{ Presentation } \\
\hline Cephalic & . & 56 \\
\hline Breech . . . & . & 4 \\
\hline Not recorded or known & . & 22 \\
\hline \multicolumn{3}{|l|}{ Birth weight } \\
\hline \multirow{3}{*}{$\begin{array}{l}\text { Less than } 2 \cdot 27 \text { kilograms } \\
2 \cdot 27 \text { to } 3 \cdot 18 \text { kilograms } \\
\text { More than } 3 \cdot 18 \text { kilograms }\end{array}$} & . & 20 \\
\hline & . & 50 \\
\hline & . & 12 \\
\hline \multicolumn{3}{|l|}{ Neonatal complications } \\
\hline Cyanosis, briefly & & 1 \\
\hline \multicolumn{2}{|c|}{ Fractures at birth ( 6 in 3 patients) } & 3 \\
\hline Feeding problems & & 6 \\
\hline
\end{tabular}

VOL. 52 B, NO. 3, AUGUST 1970 
cord in the cervical and lumbar regions, with increase in ventricular size, has been described (Ek 1958, Fowler 1959, Drachman and Banker 1961, Adams et al. 1962).

Microscopically the changes in the muscle are loss of fibres with fatty or fibrous replacement, variation in fibre size, and displacement of some cell nuclei towards the centre of the fibres (Figs. 1 and 2). Our own biopsy material illustrates these local changes, but not the diminution of anterior horn cells described by other observers.

One thirteen-year-old boy with arthrogryposis and many deformities died suddenly a week after his ninth operation. Extensive dissection showed generalised atrophy but no fibro-fatty replacement of muscle. Microscopic sections of ten muscles showed only mild atrophy, with slight increase in fibrous tissue. Three peripheral nerves, ten areas of brain and ten levels of spinal cord were normal histologically. The disease could not be classified as neuropathic or myopathic.

A six-year-old boy with arthrogryposis and mild spasticity and athetosis had amputations through both knees to allow him to wear artificial limbs and learn for the first time to walk. The legs were very thin and contained no identifiable muscle tissue, only fibro-fatty material with exaggerated intermuscular septa and a normal complement of tendons. The joints were held rigid by tight thick capsules. Microscopic sections showed only fatty masses containing an occasional muscle fibre and a little collagen. Peripheral nerves were small and when stained by the Loyez method were found to have no myelin sheaths. Because of the clinical evidence of central nervous system involvement and the defective peripheral nerves this boy's arthrogryposis was considered neurogenic.

The study of necropsy and amputation specimens demonstrated that the tissue changes in arthrogryposis were variable.

\section{THE CLINICAL PICTURE OF ARTHROGRYPOSIS IN OUR PATIENTS}

Our study was based on 114 patients (Table I) whose birth dates were fairly evenly distributed over fifteen years. There were a few more boys than girls. Careful enquiry revealed very few congenital anomalies in the relatives of our patients (Table II). There were no twins

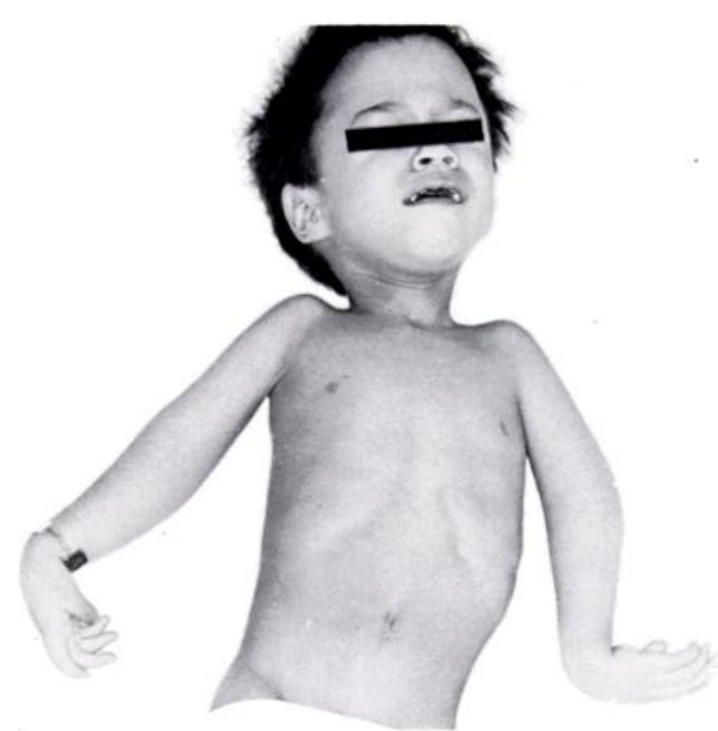

Fig. 3

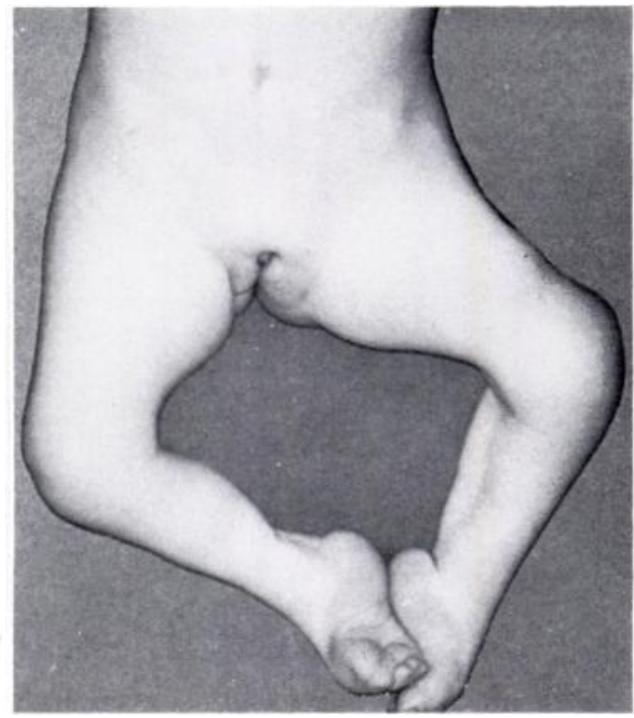

Fig. 4

Figure 3-The position of the upper limbs, the extended fusiform elbows with no flexion creases and the bizarre hands are typical of upper limb involvement in arthrogryposis. Figure 4-The hip flexion and external rotation, knee flexion and foot deformities shown here are fixed and are common in lower limb involvement in arthrogryposis. 
in the series. A number of mothers had noticed that the foetus was inactive: twenty babies out of eighty-two were under $2 \cdot 3$ kilograms at birth and three had sustained fractures of both femoral shafts during delivery (Table III). Many patients had some associated anomaly (Table IV).

All patients had fixed deformities of joints, usually bilateral but seldom exactly symmetrical. Untreated deformities became more rigid during growth and partly corrected ones recurred, but the condition itself was not progressive. The skin was smooth and thin, sweated poorly, but healed well. About one patient in four had generalised webbing of the skin at the usual

TABLE IV

Associated Anomalies (Eighty-two Patients)

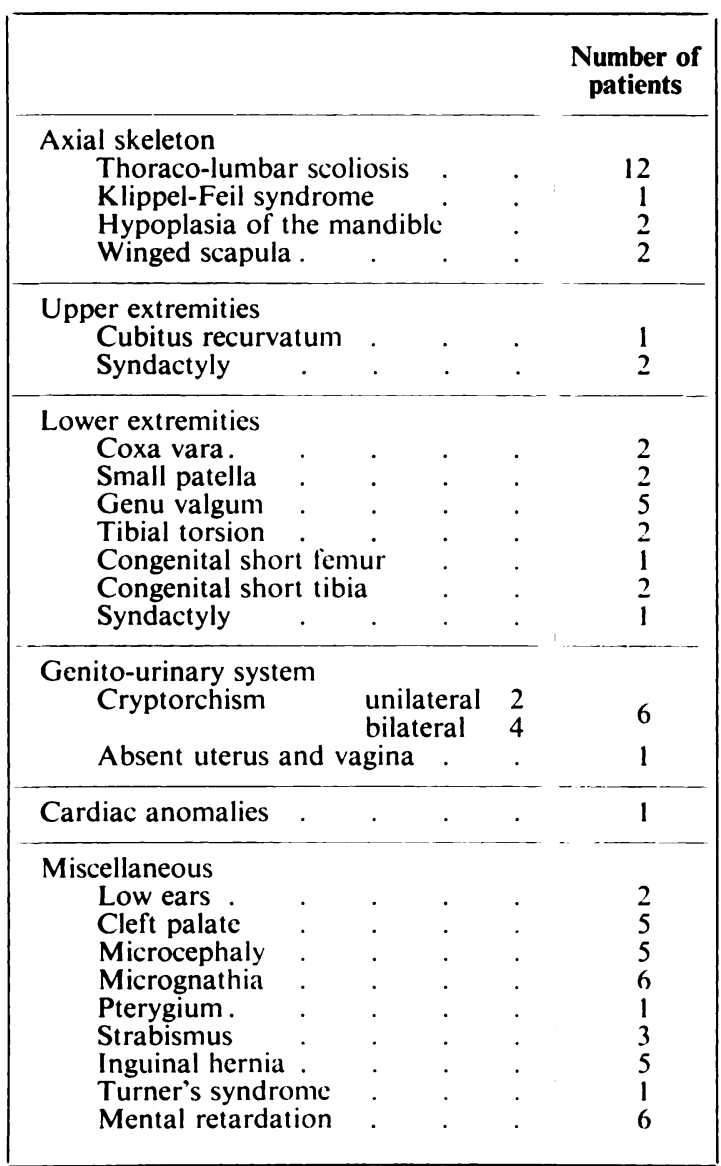

sites of flexion and lacked flexor skin creases. The subcutaneous tissue was often scanty, and the poor muscle mass made the limbs appear atrophic. The muscles were weak and the tendon reflexes diminished or absent, but proprioception was intact and balance adequate. Psychometric tests, when done, gave values for intelligence quotient within the normal range. Among those not tested, a few were conspicuously retarded. The face often lacked expression because of muscle inactivity and the neck was sometimes short. Twelve patients (out of eighty-two) had scoliosis.

In the upper limbs (Table V) the shoulders were rounded and held in adduction and medial rotation. The elbows were either stiff in extension and fusiform in outline, or stiff in flexion with some webbing of the skin. Forearms were usually pronated, wrists flexed and the metacarpo-phalangeal and interphalangeal joints stiff in varying combinations of extension and flexion (Fig. 3). 
In the lower limbs (Table VI) the hips were often involved, being sometimes dislocated, less often merely flexed, and occasionally fixed in flexion, abduction and lateral rotation.

TABLE V

Deformities of the UpPer Extremities (EIghty-two Patients)

\begin{tabular}{|c|c|c|}
\hline Abnormality & & $\begin{array}{c}\text { Number of } \\
\text { patients }\end{array}$ \\
\hline $\begin{array}{l}\text { Shoulders ( } 16 \text { patients) } \\
\text { Adduction and medial rotation }\end{array}$ & $\begin{array}{lr}\text { unilateral } & 2 \\
\text { bilateral } & 14\end{array}$ & 16 \\
\hline $\begin{array}{l}\text { Elbows ( } 21 \text { patients) } \\
\text { Flexion deformity } \\
\text { Extension deformity } \\
\text { Dislocated radial head }\end{array}$ & $\begin{array}{lr}\text { unilateral } & 0 \\
\text { bilateral } & 8 \\
\text { unilateral } & 0 \\
\text { bilateral } & 10 \\
\text { unilateral } & 0 \\
\text { bilateral } & 3\end{array}$ & $\begin{array}{r}8 \\
10 \\
3\end{array}$ \\
\hline $\begin{array}{l}\text { Wrists ( } 27 \text { patients) } \\
\text { Flexion deformity } \\
\text { Flexion and ulnar deviation } \\
\text { Pronation contracture }\end{array}$ & $\begin{array}{lr}\text { unilateral } & 0 \\
\text { bilateral } & 9 \\
\text { unilateral } & 0 \\
\text { bilateral } & 18 \\
. & .\end{array}$ & $\begin{array}{l}18 \\
19\end{array}$ \\
\hline $\begin{array}{l}\text { Hands ( } 22 \text { patients) } \\
\text { Flexion of fingers } \\
\text { Flexion and ulnar deviation of } \\
\text { Extension of metacarpo-phalan } \\
\text { Thumb-in-palm hand } \\
\text { Narrow first web space }\end{array}$ & $\begin{array}{l}\text { fingers } \\
\text { igeal joints } \\
\text { i. } \\
. \\
.\end{array}$ & $\begin{array}{r}7 \\
20 \\
8 \\
17 \\
13\end{array}$ \\
\hline
\end{tabular}

TABLE VI

Deformities of the Lower Extremities (Eighty-two Patients)

\begin{tabular}{|c|c|c|}
\hline Deformity & & $\begin{array}{c}\text { Number of } \\
\text { patients }\end{array}$ \\
\hline $\begin{array}{l}\text { Hips ( } 42 \text { patients affected) } \\
\text { Dislocation } \\
\text { Flexion deformity } \\
\text { Flexion, abduction, lateral rotation }\end{array}$ & $\begin{array}{lr}\text { unilateral } & 9 \\
\text { bilateral } & 18 \\
\text { bilateral } & 5 \\
\text { bilateral } & 10\end{array}$ & $\begin{array}{r}27 \\
5 \\
10\end{array}$ \\
\hline $\begin{array}{l}\text { Knees (40 patients affected) } \\
\text { Flexion deformity } \\
\text { Extension fixed } \\
\text { Subluxation }\end{array}$ & $\begin{array}{lr}\text { unilateral } & 4 \\
\text { bilateral } & 19 \\
\text { unilateral } & 2 \\
\text { bilateral } & 9 \\
\text { unilateral } & 4 \\
\text { bilateral } & 2\end{array}$ & $\begin{array}{l}23 \\
11\end{array}$ \\
\hline $\begin{array}{l}\text { Feet (68 patients affected) } \\
\text { Equinovarus } \\
\text { Rigid calcaneo-valgus } \\
\text { Rockerbottom foot }\end{array}$ & $\begin{array}{lr}\text { unilateral } & 5 \\
\text { bilateral } & 56 \\
\text { unilateral } & 3 \\
\text { bilateral } & 3 \\
\text { bilateral } & 1\end{array}$ & $\begin{array}{r}61 \\
6 \\
1\end{array}$ \\
\hline
\end{tabular}

Knees were often stiff in extension and subluxed, or fixed in flexion. Ankles and feet were usually in equinovarus, but an occasional calcaneo-valgus deformity with vertical talus was seen (Fig. 4). 


\section{MANAGEMENT OF ARTHROGRYPOSIS}

If an arthrogrypotic child dies it is usually from respiratory infection (Table VII). Therefore, to preserve life, respiratory disease must be prevented if possible or treated vigorously. The problems of weakness and deformity then remain. To gain some joint mobility it is necessary to start frequent gentle stretchings of the joint contractures very early in life. After a few months these stretchings become less effective and need to be supplemented by serial moulded plasters. If the deformities are corrected, braces or splints may be needed to prevent recurrence. If they

TABLE VII

Deaths in Whole Group of 114 Patients

\begin{tabular}{|c|c|c|}
\hline $\begin{array}{l}\text { Infants } \\
\text { Respiratory problems } \\
\text { Gastroenteritis }\end{array}$ & 10 & 11 \\
\hline $\begin{array}{l}\text { Children under five years of age } \\
\text { Respiratory problems }\end{array}$ & 3 & 3 \\
\hline $\begin{array}{l}\text { Pre-adolescent (14 years) } \\
\text { Post-operative hyperpyrexia }\end{array}$ & $\mathrm{i}$ & 1 \\
\hline Total. & . & 15 \\
\hline
\end{tabular}

TABLE VIII

Operations on the Upper Limb (Eighty-two Patients)

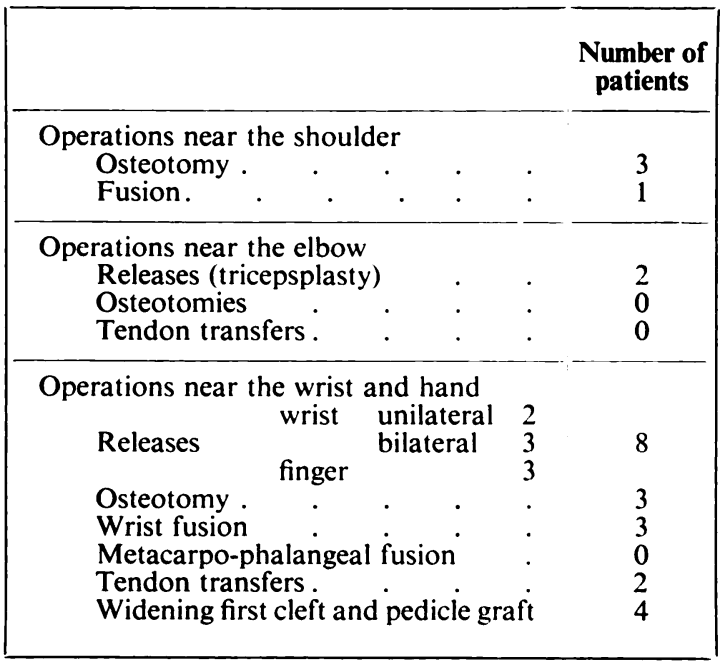

are not, then the adaptive changes in cartilage and bone occurring during growth will consolidate the limitation of joint function. If correction by these methods is inadequate, operation is needed.

Our patients have had relatively few operations for correction of upper limb deformities, possibly fewer than they should have had (Table VIII). Rotation osteotomy of the humerus overcomes marked medial rotation deformity at the shoulder, and arthrodesis of a weak shoulder makes the whole limb useful when involvement is chiefly proximal.

Flexed elbows are usually left alone, but when both elbows are extended it is desirable to try to get enough flexion of one elbow to allow a hand to approach the hair, face and mouth. Apposition of the two hands should still be possible. To achieve this, elbow release with transfer of the triceps or pectoralis major, or with proximal transplantation of the forearm

VOL. 52 B, NO. 3, AUGUST 1970 
flexor origin have been used, with only modest benefit, because these muscles are seldom strong even before transfer.

In the wrist and hand few operations were done. Soft-tissue releases early in life make subsequent treatment of wrist flexion easier. Flexor carpi ulnaris transfer is effective, and, near the end of growth, fusion of the wrist may be helpful. This should be recommended, however, with great caution and only after the patient has tested hand function with the wrist splinted,

TABLE IX

Opirations on the Lower limb (Eigihty-two Patif nts)

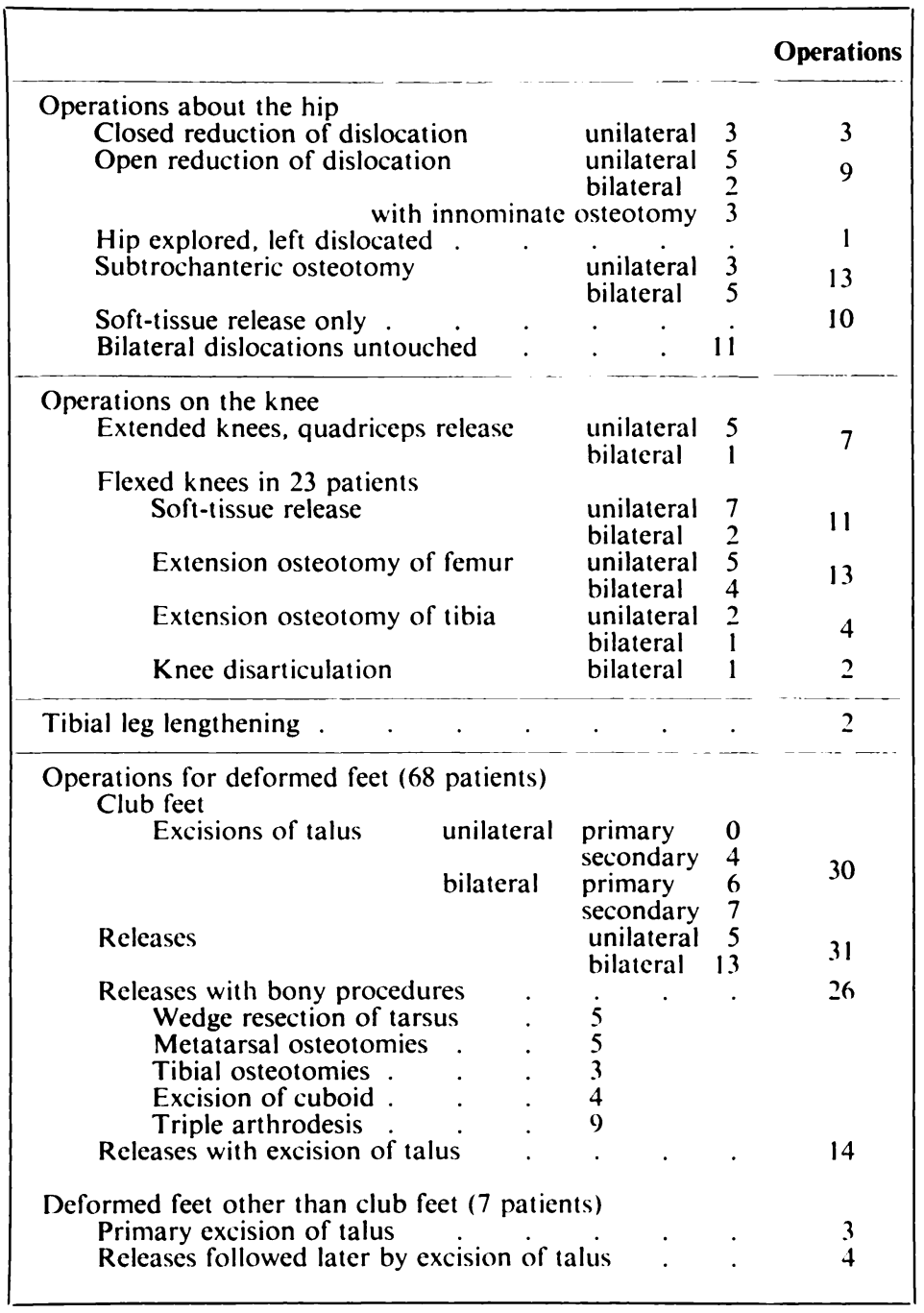

because borderline finger function may be ruined by wrist fixation. For the hand, transfers of already weak muscles are not useful. By long practice these children have acquired skills with unusual patterns of movement, suited to their deformities.

Three patients had spinal fusion for scoliosis.

Many operations were done on the lower limbs (Table IX). High bilateral hip dislocations were left untreated because they are neither unstable nor painful, and attempts at treatment may produce either bilateral stiff painful hips or high bilateral rigid dislocations, surrounded by scar tissue. In a mobile unilateral hip dislocation, release of tight structures, including that 
of the tendon of the iliopsoas, followed by traction, facilitates open or closed reduction during the first few months of life. Later, persistent hip flexion deformities will make walking difficult, but the lower limbs can be brought into a functional relationship with the body by subtrochanteric osteotomy of the femora.

Subluxated hyperextended knees need a quadricepsplasty to give useful flexion. Flexed knees require posterior releases, including sometimes division of the cruciate and collateral ligaments. Actual extension of the knee and stretching of the neurovascular bundle must be gradual. In older children extension osteotomies may be required. Two children in our series had tibial lengthening for discrepancy of leg length.

Among our patients most foot deformities required extensive surgical release of the soft tissues and many of the resistant ones also needed excision of the talus for adequate correction.

\section{RESULTS}

Objective assessment of the results of operation is difficult because the severity of the original deformity varies greatly, and the outcome of treatment cannot fairly be judged by comparisons within or without the group. Even quite modest functional gains are warmly appreciated by the patients.

The forty-eight patients with upper limb involvement were largely self-sufficient. All who were old enough fed and dressed themselves, except for tying shoe laces and fastening upper shirt buttons. The patients and the authors believe that the operations improved function. We were impressed by the skill with which weak deformed hands were used. It was clear, however, that most of these patients will still be grossly handicapped as adults for manual work.

TABLE $X$

Results of TReatment

\begin{tabular}{|c|c|c|c|}
\hline \multicolumn{2}{|c|}{ Result } & Comment & \multirow{2}{*}{$\frac{\text { Number }}{6}$} \\
\hline Bedridden. & . & $\begin{array}{l}\text { Three untreated. } \\
\text { Three had eighteen operations between them }\end{array}$ & \\
\hline Wheelchair & . & $\begin{array}{l}\text { Only one was untreated. } \\
\text { Two could walk with braces but preferred } \\
\text { the wheelchair }\end{array}$ & 12 \\
\hline Walking wit & oraces . & All had needed several operations to achieve this & 19 \\
\hline Walking wit & ut braces & All had needed several operations to achieve this & 38 \\
\hline Upper limb i & olvement only & - & 7 \\
\hline Total & . & & 82 \\
\hline
\end{tabular}

The seventy-five patients with lower limb involvement achieved a functional result varying from being bedridden to being able to walk unaided (Table $\mathrm{X}$ ). Three patients confined to bed had had eighteen operations among them in vain. The patients confined to wheel-chairs had had an average of four operations each, of which only one procedure, a quadricepsplasty, was a help. All the operations done for those able to walk had contributed to this happy outcome and were considered to have been worth while.

\section{DISCUSSION}

Our patients and the surgeons who treated them considered the results of limited operations on the upper limb satisfactory, although some surgeons might have recommended more operations than were offered (Weeks 1967).

Vol. 52 B, NO. 3, AUgust 1970 
In contrast, a large number of operations were performed for lower limb deformitics (Table IX). This seems to be the case whenever a large series of patients is reported. Thus Mead, Lithgow and Sweeney (1958) reported 122 operations in forty cases, and Friedlander, Westin and Wood (1968) 424 operations in forty-five cases. Statistical analysis of the results of treatment of any particular deformity or of any particular operative procedure had little meaning. Not only were the children growing and developing an increasing functional potential unrelated to treatment, but the age and condition of the patient before operation. the details of surgical technique, the length of time since the operations and the ages of the patients at review all varied.

It was clear, however, that early treatment was more effective than late in controlling deformity and improving function. Unfortunately, application of this observation will result in some children who are later recognised as being grossly retarded receiving treatment. We think that, provided this possibility is remembered, it is better to err on the side of providing care than of withholding it.

Many release procedures had to be repeated. It is wise, therefore, to release soft tissues as completely as possible at the first operation. Because of adaptive changes in the joints release procedures are progressively less effective as the child grows, and so correction should be obtained by operation through bone. Both the patient's parents and the surgeon should recognise at the beginning of treatment that numerous procedures may be needed.

Club foot releases permit correction of forefoot varus, but leave a degree of rigid equinus which cannot successfully be treated by release of the tendo calcaneus and posterior capsulotomy. Excision of the talus proves satisfactory, gives lasting correction and, in the older children, feet which continue symptom-free.

The long-term results of the management of this condition are not known. In a previous study an effort was made to trace a few patients treated twenty-five years before, and of these three were seen. One was a mother of three normal boys; another a housewife who had adopted two children; and the third a single man who was supporting himself.

In the current review it was noticeable that many home situations had been severely strained by the distress and by the burden of care associated with these deformed children. Some of the homes seemed at breaking point. From the time the parents are first told that their child has a problem they need special consideration and support (Gibson 1968).

Improved surgical skill and ingenuity may in the future achieve better results, or even the same results, but with fewer operations. The severity of the original involvement sets a limit on the quality of the final function. Real progress will only follow new insight into the nature of this condition. These will come either from clinical investigations considerably more exhaustive than we have used in the past, or from animal experiment. Both are needed.

\section{SUMMARY AND CONCLUSIONS}

1. Eighty-two patients out of 114 with arthrogryposis seen at the Hospital for Sick Children, Toronto, during the period of 1950-65 have been studied, and the literature has been reviewed.

2. Arthrogryposis is considered to be caused by a failure of normal development.

3. Respiratory infection in the first five years is the major hazard to life. If these children survive the first five years, the expectation is that they will reach maturity and find a place in the community.

4. Children with upper limb involvement develop remarkably good function which can be improved by carefully planned operations.

5. Operation has a much larger place in the treatment of affected lower limbs.

6. Three out of four children with lower limb involvement can be enabled to walk if the need for repeated operation is accepted.

7. Excision of the talus is a useful operation in the management of club foot in arthrogryposis.

8. Early treatment is more effective than late in controlling deformity and improving function. 
The authors wish to acknowledge their indebtedness to Mr James Coombs who assisted in a pilot survey, to Dr D. C. Birdsell who prepared the reports on the necropsy and amputation specimens, and to the Surgical Study Fund of the Department of Surgery of the Hospital for Sick Children for financial support.

\section{REFERENCES}

Adams, R. D., Denny-Brown, D., and Pearson, C. M. (1962): Diseases of Muscle; a Study in Pathology. Second edition. New York: 310 Hoeber Medical Division of Harper \& Brothers.

BADGLey, C. E. (1943): Correlation of Clinical and Anatomical Facts Leading to a Conception of the Etiology of Congenital Hip Dysplasias. Journal of Bone and Joint Surgery, 25, 503.

BankeR, B. Q., Victor, M., and Adams, R. D. (1957): Arthrogryposis Multiplex Due to Congenital Muscular Dystrophy. Brain, 80, 319.

Brand, S. (1947): A Case of Arthrogryposis Multiplex Congenita Anatomically Appearing as a Foetal Spinal Muscular Atrophy. Acta Paediatrica, 34, 365.

Соок, L. C. (1936): Amyoplasia Congenita Associated with Mongolism. Archives of Disease in Childhood, ii, 261.

Drachman, D. B., and Banker, B. Q. (1961): Arthrogryposis Multiplex Congenita. Archives of Neurology, $5,77$.

Drachman, D. B., and Coulombre, A. J. (1962): Experimental Clubfoot and Arthrogryposis Multiplex Congenita. Lancet, ii, 523.

EK, J. I. (1958): Cerebral Lesions in Arthrogryposis Multiplex Congenita. Acta Paediatrica, 47, 302.

Fowler, M. (1959): A Case of Arthrogryposis Multiplex Congenita with Lesions in the Nervous System. Archives of Disease in Childhood, 34, 505.

Friedlander, H. L., Westin, G. W., and Wood, W. L. Jun. (1968): Arthrogryposis Multiplex Congenita. Journal of Bone and Joint Surgery, 50-A, 89.

GiBSON, D. A. (1968): Arthrogryposis. Canadian Journal of Surgery, 11, 506.

Gilmour, J. R. (1946): Amyoplasia Congenita. Journal of Pathology and Bacteriology, 58, 675.

Hillman, J. W., and Johnson, J. T. H. (1952): Arthrogryposis Multiplex Congenita in Twins. Journal of Bone and Joint Surgery, 34-A, 211.

Howard, R. (1908): A Case of Congenital Defect of the Muscular System (Dystrophia Muscularis Congenita) and Its Association with Congenital Talipes Equino-varus. Proceedings of the Royal Society of Medicine, London (Section of Pathology), 1, 157.

Laitinen, O., and Hirvensalo, M. (1966): Arthrogryposis Multiplex Congenita. Annales Paediatriae Fenniae, $12,133$.

LewIN, P. (1925): Arthrogryposis Multiplex Congenita. Journal of Bone and Joint Surgery, 7, 630.

Lipton, E. L., and Morgenstern, S. H. (1955): Arthrogryposis Multiplex Congenita in Identical Twins. American Journal of Diseases of Children, 89, 233.

Mead, N. G., Lithgow, W. C., and Sweeney, H. J. (1958): Arthrogryposis Multiplex Congenita. Journal of Bone and Joint Surgery, 40-A, 1285.

Middleton, D. S. (1934): Studies on Prenatal Lesions of Striated Muscle as a Cause of Congenital Deformity. I-Congenital Tibial Kyphosis. II-Congenital High Shoulder. III-Myodystrophia Foetalis Deformans. Edinburgh Medical Journal, 41, 401.

Pearson, C. M., and Fowler, W. G. Jun. (1963): Hereditary Non-Progressive Muscular Dystrophy Inducing Arthrogryposis Syndrome. Brain, 86, 75.

Price, D. S. (1933): A Case of Amyoplasia Congenita with Pathological Report. Archives of Disease in Childhood, 8, 343.

Roberts, J. A. F. (1929): The Inheritance of a Lethal Muscle Contracture in the Sheep. Journal of Genetics, $21,57$.

Shfldon, W. (1932): Amyoplasia Congenita. Archives of Disease in Childhood, 7, 117.

Stern, W. G. (1923): Arthrogryposis Multiplex Congenita. Journal of the American Medical Association, $81,1507$.

WeEks, P. M. (1967): Surgical Correction of Arthrogrypotic Deformities of the Upper Extremity. Journal of Bone and Joint Surgery, 49-A, 579.

Whiтtem, J. H. (1957): Congenital Abnormalities in Calves: Arthrogryposis and Hydranencephaly. Journal of Pathology and Bacteriology, 73, 375. 